Interhemispheric bias in earth's climate response

\title{
Interhemispheric bias in earth's climate response to orbital forcing
}

\section{R. Roychowdhury and R. M. DeConto}

Department of Geoscience, University of Massachusetts, Amherst, USA

Received: 17 October 2015 - Accepted: 8 December 2015 - Published: 15 January 2016

Correspondence to: R. Roychowdhury (rroychowdhur@geo.umass.edu)

Published by Copernicus Publications on behalf of the European Geosciences Union.

\section{Title Page}

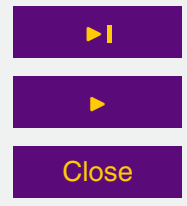

\section{Full Screen / Esc}

Printer-friendly Version

Interactive Discussion 


\section{Abstract}

The climate response to orbital forcing shows a distinct hemispheric asymmetry due to the unequal distribution of land in the Northern vs. Southern hemispheres. This asymmetry is examined using a Global Climate Model (GCM) and a Land Hemispheric Bias (LHB) is quantified for each hemisphere. The results show how changes in obliquity and precession translate into variations in the calculated LHB. We find that the global climate response to specific past orbits is likely unique and modified by complex climate-ocean-cryosphere interactions that remain poorly known and difficult to model. Nonetheless, these results provide a baseline for interpreting contemporaneous proxy climate data spanning a broad range of latitudes, which maybe especially useful in paleoclimate data-model comparisons, and individual time-continuous records exhibiting orbital cyclicity.

\section{Introduction}

The geographical arrangement of continents on the earth's surface plays a fundamen15 the result of the horizontal and vertical displacements associated with plate tectonics. While these processes are still in operation, the global continental configuration has been close to its present form since the mid-Cenozoic. Today, more continental land area is found in the Northern Hemisphere (68\%) as compared to the Southern Hemisphere $(32 \%)$. These different ratios of land vs. ocean in each hemisphere affect the balance of incoming and outgoing radiation, atmospheric circulation, ocean currents, and the availability of terrain suitable for growing glaciers and ice-sheets. As a result of this land-ocean asymmetry, the climatic responses of the Northern and Southern Hemisphere differ for an identical change in radiative forcing (Barron et al., 1984; Deconto

\section{CPD}

doi:10.5194/cp-2015-156

\section{Interhemispheric bias in earth's climate response}

R. Roychowdhury and R. M. DeConto

\section{Title Page}

Abstract Introduction

Conclusions References

Tables

Figures

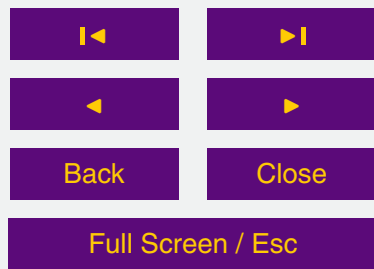

Printer-friendly Version

Interactive Discussion 
Multiple studies have shown interhemispheric asymmetry in climate response of Northern and Southern Hemispheres. Climate simulations made with coupled atmosphere-ocean GCMs typically show a strong asymmetric response to greenhouse-gas loading, with Northern Hemisphere high latitudes experiencing more 5 warming compared to Southern Hemisphere high latitudes (Flato and Boer, 2001; Stouffer et al., 1989).

GCMs also show that the Northern and Southern Hemispheres respond differently to changes in orbital forcing (e.g. Philander et al., 1996). While the magnitude of insolation changes through each orbital cycle is identical for both hemisphere, the difference 10 in climatic response can be attributed to the fact that Northern Hemisphere is landdominated while Southern Hemisphere is water dominated (Croll, 1870). This results in a stronger response to orbital forcing in the Northern Hemisphere relative to the Southern Hemisphere. In this paper we quantify this bias in the climate response to orbital forcing.

\section{Effect of continental (and oceanic) distribution on climate}

The changing continental configurations as a result of plate tectonics have been linked with climate change over a wide range of timescales (e.g. Crowley and North, 1996; DeConto, 2009; Fawcett and Barron, 1998; Hay, 1996). The distribution of continents and oceans has an important effect on the spatial heterogeneity of the Earth's energy bal-

ance, primarily via the differences in albedos and thermal properties of land vs. ocean (Trenberth et al., 2009). The latitudinal distribution of land has a dominant effect on zonally averaged net radiation balance due to it's influence on planetary albedo and ability to transfer energy to the atmosphere through long-wave radiation, and fluxes of sensible and latent heat. The latitudinal net radiation gradient controls the total poleward (Stone, 1978).

CPD

doi:10.5194/cp-2015-156

\section{Interhemispheric bias in earth's climate response}

R. Roychowdhury and R. M. DeConto

\section{Title Page}

Abstract Introduction

Conclusions References

Tables

Figures

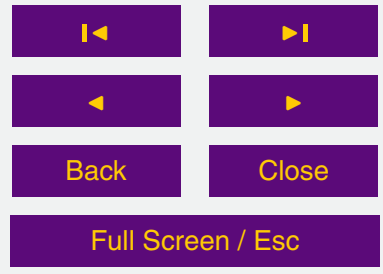

Printer-friendly Version

Interactive Discussion 
Even though modern estimates of atmospheric and oceanic heat transport remain poorly constrained, it is generally accepted that oceans contribute less than half of the total heat transport required to maintain the earth's meriodional energy balance (Bryden and Imawaki, 2001; Wunsch, 2005). Maximum poleward heat transport through the 5 oceans take place in the low latitudes, however the ocean circulation plays an important role in polar climate via its influence on atmospheric teleconnections to the tropics and its control on seasonal distributions of sea-ice. Oceans have a relatively slower response to seasonal changes in insolation due to the higher specific heat of water as compared to land, and mixing in the upper $\sim 10-150 \mathrm{~m}$ of the ocean. As a result, 10 in the ocean-dominated Southern Hemisphere, the surface waters suppress extreme temperature swings in the winter and provide the atmosphere with a source of moisture and diabatic heating. In the land dominated Northern Hemisphere, the lower heat capacity of the land combined with relatively high albedo results in greater seasonality, particularly in the interiors of large continents of Asia and North America.

15 The continentiality of the Northern Hemisphere manifests itself in different hemispherically asymmetric climatic phenomenon, like the well-known Asian monsoonal circulation system. The intertropical convergence zone (ITCZ), which is considered to be the region of low-level convergence and convective precipitation, should theoretically move equally north or south according to the hemisphere experiencing summer. However, the ITCZ moves further away from the equator during the northern summer than the southern one due to the continentiality of the Northern Hemisphere (Philander et al., 1996; Kang et al., 2008). The land surface available in a particular hemisphere also affects the potential for widespread glaciation. The extreme cold winters associated with large continents provide the means of accumulation of winter snow, while the critical factor for formation of ice-sheets is annual ablation and can be estimated by the sum of positive degree days in a year (Huybers, 2006).

Continental geography has a stronger impact on polar climates, as is evident from the differences in the climatic regimes of the Arctic and the Antarctic. Several early paleoclimate modeling studies using GCMs investigated continental distribution as a

\section{CPD}

doi:10.5194/cp-2015-156

\section{Interhemispheric bias in earth's climate response}

R. Roychowdhury and R. M. DeConto

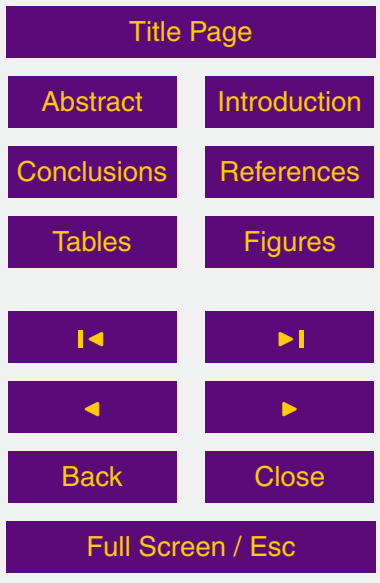

Printer-friendly Version

Interactive Discussion 
forcing factor of global climate (e.g. Barron et al., 1984; Hay et al., 1990). These studies demonstrated that an earth with its continents concentrated in the low latitudes is warmer and has lower equator-to-pole temperature gradients than an earth with only polar continents (DeConto, 2009). Although these early model simulations did not 5 incorporate all the complexities of the climate system, the results provided valuable insights from comparative studies of polar vs. equatorial continents in the earth and showed that changes in continental configuration has significant influence on climatic response to forcing.

Here we estimate the general hemispheric bias in the climate response to orbital forc10 ing by comparing results of GCM simulations using modern and idealized (hemispherically symmetric) global geographies (Fig. 1). The modern and idealized geographies are used to quantify the different climate responses to a range of orbital configurations. By comparing the climatic response of the different geographies, we isolate and estimate the bias due to modern continental geography.

\section{Methods}

\subsection{Experimental Design}

We use the latest (2012) version of the Global ENvironmental and Ecological Simulation of Interactive Systems (GENESIS) 3.0 GCM with a slab ocean component (Thompson and Pollard, 1997) rather than a full-depth dynamical ocean (Alder et al., 2011).

The slab-ocean version of the GCM allows numerous simulations with idealized global geographies and greatly simplifies interpretations of the sensitivity tests by precluding complications associated with ocean model dependencies. In addition to the atmosphere and slab-ocean, the GCM includes model components representing vegetation, soil, snow, and thermo-dynamic sea ice. The 3-D atmospheric component of the GCM uses an adapted version of the NCAR CCM3 solar and thermal infrared radiation code (Kiehl et al., 1998) and is coupled to the surface components by a land-surface-transfer

\section{CPD}

doi:10.5194/cp-2015-156

\section{Interhemispheric bias in earth's climate response}

R. Roychowdhury and R. M. DeConto

\section{Title Page}

Abstract Introduction

Conclusions References

Tables

Figures

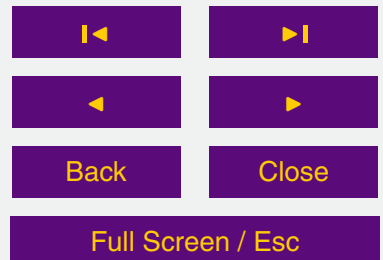

Printer-friendly Version

Interactive Discussion 
scheme (LSX). In the setup used here, the model atmosphere has a spectral resolution of T31 $\left(\sim 3.75^{\circ}\right)$ with 18 vertical layers. Land-surface components are discretized on a higher resolution $2^{\circ} \times 2^{\circ}$ grid.

The GCM uses various geographical boundary conditions (described below) in ${ }_{5} 2^{\circ} \times 2^{\circ}$ and spectral T31 grids for surface and AGCM models, respectively. For each set of experiments, the model is run for 50 years. Spin-up is taken into account, and equilibrium is effectively reached after about 20 years of integration. The results used to calculate biases are averaged over the last 20 years of each simulation. Greenhouse gas mixing ratios are identical in all experiments and set at preindustrial levels with $\mathrm{CO}_{2}$ 10 set at $280 \mathrm{ppmv}, \mathrm{N}_{2} \mathrm{O}$ at $288 \mathrm{ppbv}$ and $\mathrm{CH}_{4}$ at $800 \mathrm{ppb}$. The default values for $\mathrm{CFCl}_{3}$ and $\mathrm{CF}_{2} \mathrm{Cl}_{2}$ values are set at $0 \mathrm{ppm}$. The solar constant is maintained at $1367 \mathrm{Wm}^{2}$.

\subsection{Asymmetric and Symmetric Earth Geographies}

The GCM experiments are divided into three sets: (1) Preindustrial CONTROL (2) NORTH-SYMM and (3) SOUTH-SYMM. The Preindustrial CONTROL experiments use 15 a modern global geography spatially interpolated to the model's $2^{\circ} \times 2^{\circ}$ surface grid (Koenig et al., 2012). The geography provides the land-ice sheet-ocean mask and land-surface elevations used by the GCM.

To simulate the climate of an Earth with meriodionally symmetric geographies, we created two sets of land surface boundary conditions: NORTH-SYMM and SOUTHSYMM. For the NORTH-SYMM experiments, the CONTROL experiment boundary conditions are used to generate a modified GCM surface mask, by reflecting the Northern hemisphere geography (land-sea-ice mask, topography, vegetation, soil texture) across the equator into the Southern hemisphere. Similarly, in the experiment SOUTH-SYMM, the land mask and geographic boundary conditions in the Southern Hemisphere are ary conditions are shown in Fig. 1b and c, with the modern (Fig. 1a) for comparison.

CPD

doi:10.5194/cp-2015-156

\section{Interhemispheric bias in earth's climate response}

R. Roychowdhury and R. M. DeConto

\section{Title Page}

Abstract Introduction Conclusions References Tables Figures

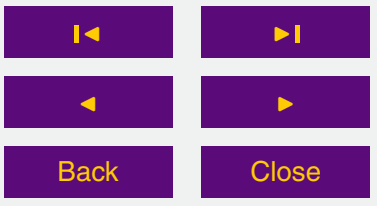

Full Screen / Esc

Printer-friendly Version

Interactive Discussion 


\subsection{Orbits}

The orbital parameters used in the experiments are idealized and do not correspond to a specific time in Earth's history. Rather, they are designed to provide a useful framework for isolating the effects of precession and obliquity on the estimated bias. HIGH 5 and LOW orbits approximate the highest and lowest obliquity in the last three million years (Berger and Loutre, 1991). NHSP (Northern Hemisphere Summer Perihelion) and SHSP (Southern Hemisphere Summer Perihelion) orbits correspond to northern and austral summers coinciding with perihelion respectively, and represent the two extreme configurations of precession with obliquity set at its mean value averaged over the last 3 million years. Eccentricity is set at the same moderate value (mean eccentricity over the last 3 million years) for all simulations. Table 1 summarizes the orbits used in the ensemble of model simulations.

\section{Results of symmetry experiments}

We first test for asymmetry in the climate response to changes in orbital forcing by 15 each simulation. The integrated summer energy $(J)$ is a proxy for the influence of orbital forcing at the top of the atmosphere, and is defined as $J=\sum_{i} \beta_{i}\left(W_{i} \times 86400\right)$, where $W_{i}$ is mean insolation measured in $W^{-2}$ on day $i$, and $\beta$ equals 1 when $W_{i} \geq \tau$ and zero otherwise. $\tau=275 \mathrm{~W} \mathrm{~m}^{-2}$ is taken as the assumed threshold for melting of ice at the earth's surface. The Summer Metric $(S)$ defined below is a better indicator of air temperature's influence on annual ablation over ice sheets. It is defined as $S=$ $\sum_{i} \propto_{i} T_{i}$ where $T_{i}$ is the mean daily temperature on day $i$, and $\alpha$ is one when $T_{i} \geq 0{ }^{\circ} \mathrm{C}$ and zero otherwise. The integrated summer insolation metrics $(J$ and $S$ ) are versatile climate indicators, and capture the extremity and duration of the melt season. While the atmosphere, the calculation of the Summer Metric $(S)$ is more involved. Rather

\section{CPD}

doi:10.5194/cp-2015-156

\section{Interhemispheric bias in earth's climate response}

R. Roychowdhury and R. M. DeConto

Title Page

Abstract Introduction

Conclusions References

Tables Figures

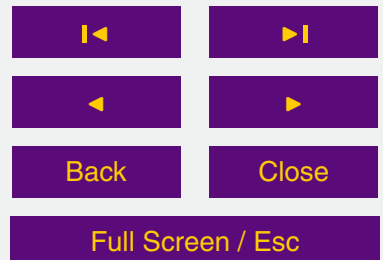

Printer-friendly Version

Interactive Discussion 
than assuming an empirical relationship between insolation and temperature based on simple radiative transfer theory (Huybers, 2006), we calculate $S$ using temperatures simulated by the GCM, which includes representations of both radiation physics and atmospheric dynamics.

$5 \quad$ At the top of the atmosphere, changes in summer energy $(J)$ are exactly symmetrical across the equator (Fig. 2), and simple radiative transfer theory would lead us to expect symmetry in the earth's climate response. Here, we use the GCM to demonstrate the asymmetric climate response of the Earth to orbital forcing. The plots in Fig. 3 show the meriodional increase (or decrease) in the Summer Metric $(S)$, normalized to represent 10 the response to a precessional change (Fig. 3a and b) and an obliquity change (Fig. 3c and d). If we make the continents meriodionally symmetric, the climate response to orbital forcing becomes similar in both hemispheres (Fig. 4).

\section{Estimation of bias}

The observed asymmetry in the climate response to orbital forcing can be postulated 15 to arise from the way the continents are distributed on the earth's surface. To quantify this effect, we define an orbital-response "Land Hemisphere Bias" (LHB) imposed on the Northern Hemisphere by the Southern Hemisphere and vice-versa. We define this "land bias" as follows:

For Northern Hemisphere: $\hat{b}=\frac{1}{n} \sum_{i}^{n}\left(T_{i}^{\text {control }}-S_{i}^{\text {north }}\right)$

20 For Southern Hemisphere: $\hat{b}=\frac{1}{n} \sum_{i}^{n}\left(T_{i}^{\text {control }}-S_{i}^{\text {south }}\right)$

where $T_{i}$ is the mean daily temperature on day $i$ from the control, and $S_{i}^{\text {north }}$ is the mean daily temperature on day $i$ from the climate simulation with the north-symmetric
CPD

doi:10.5194/cp-2015-156

\section{Interhemispheric bias in earth's climate response}

R. Roychowdhury and R. M. DeConto

Title Page

Abstract

Conclusions

Tables

\section{Figures}

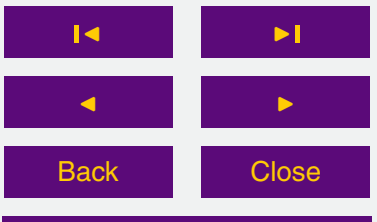

Full Screen / Esc

Printer-friendly Version

Interactive Discussion 
geography, and $S_{i}^{\text {south }}$ is the mean daily temperature on day $i$ from the south-symmetric simulation. Note that for calculation of bias, the local geography of the earth surface grid point being considered is kept constant. Only the opposite hemisphere is made symmetric. Consequently, any observed changes in climatic response at that partic5 ular grid point can be ascribed to changes in continental geography in the opposite hemisphere.

The bias is calculated at each grid point using the surface $(2 \mathrm{~m})$ air temperatures from the GCM. For different orbital configurations, we find small annual changes in bias, but seasonal (summer) bias shows a more significant response, mainly due to changes in the seasonal insolation distribution. Further, summer temperatures are more important for ablation effects on ice-sheets and forcing of Glacial-Interglacial cycles (Huybers and Denton, 2008). Here, we estimate the bias in climate forcing based on summer temperatures for each hemisphere. Figure 5 shows the estimated bias for the present day orbital configuration. Figure 6 shows the bias maps for extreme orbital configurations: 15 NHSP (Northern Hemisphere Summer at Perihelion); SHSP (Southern Hemisphere Summer at Perihelion); HIGH (Highest obliquity orbit); and LOW (Lowest obliquity orbit).

\section{Results}

The hemispheric land asymmetry bias can be positive or negative, and may be as large as $6^{\circ} \mathrm{C}$ in magnitude. This bias stems from an amplified (stronger) or muted (weaker) climatic response to orbital forcing in each hemisphere. This "land effect" has important consequences for glacial-interglacial cycles. In this section, we also describe how the changes in orbital configuration affect the LHB.

\section{CPD}

doi:10.5194/cp-2015-156

\section{Interhemispheric bias in earth's climate response}

R. Roychowdhury and R. M. DeConto

\section{Title Page}

Abstract Introduction

Conclusions References

Tables Figures

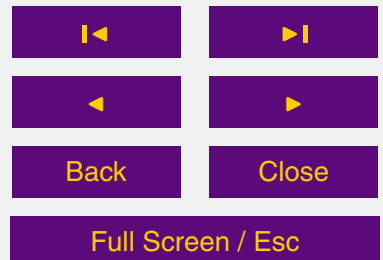

Printer-friendly Version

Interactive Discussion 


\subsection{General trends}

The bias varies with different orbital configurations, however some general trends can be identified. Generally, the Northern Hemisphere landmasses show a negative temperature bias relative to a symmetric earth. For North America and Eurasia, we focus 5 on the months of June-July-August (JJA), when the insolation intensity over the Northern Hemisphere is the strongest. Due to the asymmetry in the continental geography, the warming response to the elevated summer insolation intensities is weakened over North America and Eurasia. Consequently, summer temperatures over Northern Hemisphere continents are lower by $3-6{ }^{\circ} \mathrm{C}$ relative to a symmetric earth. In Fig. 5, this lowerthe Southern Hemisphere, we focus on the months of December-January-February (DJF), when insolation intensity over Southern Hemisphere is strongest. The warming response to elevated summer insolation intensities is strengthened in the Southern Hemisphere due to the continental geography. Importantly, the Southern Ocean has

15 a perennial positive bias, the magnitude of which changes with different orbits. During all orbits, summer temperatures over Antarctica are higher in the Control run than in the symmetric runs. Consequently, we observe a positive LHB and elevated summer temperatures over the Southern Ocean and Antarctica (yellow to red on the color scale).

\subsection{Precessional changes in LHB}

Changes in precessional primarily affect seasonal insolation intensity which is well known to be out-of-phase in both hemispheres (e.g. Raymo, 2006). The Northern Hemisphere landmasses show a strong negative bias when perihelion coincides with Northern Hemisphere summer (NHSP). In this orbit, the Northern Hemisphere experiences elevated summer insolation, but the response is weakened due to the land bias. This dampening effect is greatest in the interiors of the Northern Hemisphere continents (Fig. 6a). According to Milankovitch theory, the Northern Hemisphere should ex-

\section{Interhemispheric bias in earth's climate response}

R. Roychowdhury and R. M. DeConto

\section{Title Page}

Abstract

Conclusions Introduction

\section{4} 4

Back

\section{Full Screen / Esc}

Printer-friendly Version

Interactive Discussion 
perience "interglacial" conditions when perihelion coincides with boreal summer. However, because of the "land effect", interglacial (warm summer) conditions are muted relative to those on a symmetric earth. During this orbit, the Southern Hemisphere experiences "glacial" (relatively cold summer) conditions due to the weaker summer 5 insolation. However, the positive bias in the Southern Hemisphere leads to lesser summer cooling than on a symmetric earth. Thus, when perihelion coincides with Northern Hemisphere summer, the "land effect" dampens the magnitude of "glacial" vs. "interglacial" conditions in both hemispheres.

When perihelion coincides with Southern Hemisphere summer (SHSP), the south10 predict "interglacial" conditions in the Southern Hemisphere. Because the Southern
Hemisphere has a positive land bias, warming is amplified in this hemisphere (Fig. 6b). Conversely, the Northern Hemisphere continents have a weakly negative land bias with this orbital configuration, leading to slightly colder conditions than expected. Thus, the 15 "land effect" causes an intensification of "glacial" vs. "interglacial" conditions in both hemispheres when perihelion coincides with Southern Hemisphere summer.

\subsection{Obliquity changes in LHB}

In contrast to precession, obliquity alters the seasonality of insolation equally in both hemispheres (Fig. 2c and d). A reduction in the tilt from $24.5^{\circ}$ ( $\mathrm{HIGH}$ obliquity orbit) to $2022^{\circ}$ (LOW obliquity orbit) reduces annual insolation by $\sim 17 \mathrm{~W} \mathrm{~m}^{-2}$ and summer insolation by $\sim 45 \mathrm{~W} \mathrm{~m}^{-2}$ in the high latitudes. In the tropics, summer insolation increases by up to $\sim 5 \mathrm{~W} \mathrm{~m}^{-2}$. Loutre et al. (2004) among others predicted that global ice volume changes at the obliquity periods could be interpreted as a response to mean annual insolation and insolation gradients.

25 At HIGH obliquity, there exists a negative bias on Northern Hemisphere continents (Fig. 6c), which somewhat mutes the strong insolation intensity during summer months. In the Northern Hemisphere, as a result of continental asymmetry, a decrease in the equator to pole temperature gradient is observed (Lee and Poulsen, 2008). A lowering

\section{CPD}

doi:10.5194/cp-2015-156

\section{Interhemispheric bias in earth's climate response}

R. Roychowdhury and R. M. DeConto

\section{Title Page}

Abstract Introduction

Conclusions References

Tables Figures

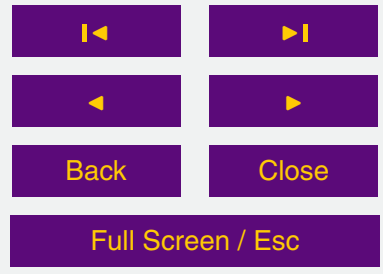

Printer-friendly Version

Interactive Discussion 
of summer temperatures and temperature gradient due to the "land bias" has a negative impact on the deglaciation trigger associated with HIGH obliquity orbits. Thus the "land bias" effect would hinder the melting of ice during high obliquity orbits. At LOW obliquity, the negative bias over Northern Hemisphere continents is generally less in5 tense (Fig. 6d). However, even a slight lowering of summer temperatures due to the continental geography would support the growth of ice sheets. In the Southern Hemisphere, the positive "land bias" over Antarctica and the Southern Ocean leads to overall higher temperatures in the high southern latitudes as compared to a symmetric earth. At HIGH obliquity orbits, this positive bias would contribute to deglaciation and at LOW 10 obliquity orbits, the positive LHB would hinder the growth of ice sheets.

\section{Conclusions}

The unbalanced fraction of land in the Northern vs. Southern Hemisphere has remained almost unchanged for the last tens of millions of years. However, the significance of this continental asymmetry on Earth's climate response to forcing has not 15 been previously quantified with physically based climate models. We find that continental geography has an important control on the climate system's response to insolation forcing, and this may hold the answer to many of the perplexing questions regarding the non-linear response of the earth's climate to insolation forcing.

According to classical Milankovitch theory, the growth of polar ice sheets at the onset 20 of glaciation requires cooler summers in the high latitudes, in order for snow to persist through the year. During warm summers at the high latitudes, the winter snow melts, leading to deglaciation. Thus, the intensity of summer insolation at high latitudes, especially the northern polar latitudes, has been considered an important driver of the glacial-interglacial cycles and other long-term climatic variations (e.g. Milankovitch, 1941). At precessional periods, at which the high latitude summer intensity primarily varies, the LHB plays an important role by amplifying (or weakening) the effect of summer insolation intensity.

\section{CPD}

doi:10.5194/cp-2015-156

\section{Interhemispheric bias in earth's climate response}

R. Roychowdhury and R. M. DeConto

\section{Title Page}

Abstract Introduction Conclusions References Tables Figures

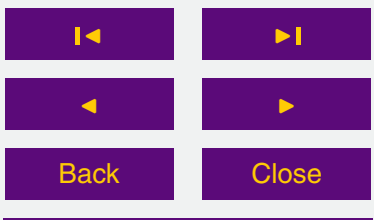
Full Screen / Esc

Printer-friendly Version

Interactive Discussion 
In all the orbital configurations simulated here, we find that the high Northern Hemisphere latitudes have a negative bias in summer temperatures. Consequently, this leads to a larger latitudinal gradient in summer temperatures in the Northern Hemisphere compared to a symmetric earth, leading to increased evaporation in the equa5 torial regions and increased precipitation in higher latitudes. Hence, in addition to the land-temperature bias, the increased latitudinal summer temperature gradient has important consequences for meridional heat and moisture transport, which in turn has important implications for the growth and demise of ice sheets (Lee and Poulsen, 2008; Raymo and Nisancioglu, 2003). In particular, the amplification (or weakening) of the re10 sponse to insolation changes at precessional and obliquity periods might explain some of the important features of late Pliocene-early Pleistocene climate variability, when obliquity-paced cyclicity dominated precession in global benthic $\delta^{18} \mathrm{O}$ records (Lisiecki and Raymo, 2005).

There are various ways in which the continental asymmetry affects Earth's climate. In 15 this paper, we have attempted to demonstrate how the LHB affects the Earth's climate response to orbital forcing via the radiative and atmospheric dynamical processes represented in a slab-ocean GCM. Future work should include complimentary simulations with AOGCMs, to explore the potential modifying role of ocean dynamics on the LHB, not accounted for here. With this study, we hope to stimulate further work focused on

Acknowledgements. This research was supported by the National Science Foundation under awards OCE 1202632 and AGS 1203910/1203792.

\section{References}

Alder, J. R., Hostetler, S. W., Pollard, D., and Schmittner, A.: Evaluation of a present-day climate 25 simulation with a new coupled atmosphere-ocean model GENMOM, Geosci. Model Dev., 4, 69-83, doi:10.5194/gmd-4-69-2011, 2011.

\section{CPD}

doi:10.5194/cp-2015-156

\section{Interhemispheric bias in earth's climate response}

R. Roychowdhury and R. M. DeConto

\section{Title Page}

Abstract Introduction Conclusions References Tables Figures

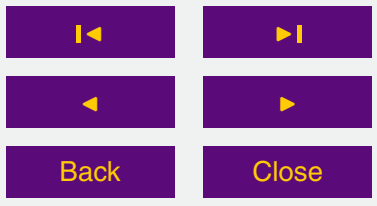

Full Screen / Esc

Printer-friendly Version

Interactive Discussion 
Barron, E. J., Thompson, S. L., and Hay, W. W.: Continental distribution as a forcing factor for global-scale temperature, Nature, 310, 574-575, doi:10.1038/310574a0, 1984.

Berger, A. and Loutre, M. F.: Insolation values for the climate of the last 10 million years, Quaternary Sci. Rev., 10, 297-317, doi:10.1016/0277-3791(91)90033-Q, 1991.

5 Bryden, H. L. and Imawaki, S.: Ocean heat transport, in Ocean Circulation \& Climate: Observing and Modelling the Global Ocean, 455-474, 2001.

Croll, J.: On ocean-currents, part I: ocean-currents in relation to the distribution of heat over the globe, Philos. Mag. J. Sci., 39, 81-106, 1870.

Crowley, T. J. and North, G. R.: Paleoclimatology, Oxford University Press, 360 pp., 1996.

10 DeConto, R.: Plate Tectonics and Climate Change, in Encyclopedia of Paleoclimatology and Ancient Environments SE - 188, edited by: Gornitz, V., Springer Netherlands, 784-798, 2009.

Deconto, R. M., Pollard, D., Wilson, P. A., Pälike, H., Lear, C. H., and Pagani, M.: Thresholds for Cenozoic bipolar glaciation, Nature, 455, 652-656, doi:10.1038/nature07337, 2008.

15 Fawcett, P. J. and Barron, E. J.: The Role of Geography and Atmospheric $\mathrm{CO}_{2}$ in Long Term Climate Change: Results from Model Simulations for the Late Permian to the Present, in Tectonic Boundary Conditions for Climate Reconstructions, Oxford University Press, 227247, 1998.

Flato, G. M. and Boer, G. J.: Warming asymmetry in climate change simulations, Geophys. Res. Lett., 28, 195-198, doi:10.1029/2000GL012121, 2001.

Hay, W. W.: Tectonics and climate, Geol. Rundschau, 85, 409-437, doi:10.1007/BF02369000, 1996.

Hay, W. W., Barron, E. J., and Thompson, S. L.: Results of global atmospheric circulation experiments on an Earth with a meridional pole-to- pole continent, J. Geol. Soc. London., 147, 385-392, doi:10.1144/gsjgs.147.2.0385, 1990.

Huybers, P.: Early Pleistocene glacial cycles and the integrated summer insolation forcing, Science, 313, 508-11, doi:10.1126/science.1125249, 2006.

Huybers, P. and Denton, G.: Antarctic temperature at orbital timescales controlled by local summer duration, Nat. Geosci., 1, 787-792, doi:10.1038/ngeo311, 2008.

30 Kang, S. M., Held, I. M., Frierson, D. M. W., and Zhao, M.: The Response of the ITCZ to Extratropical Thermal Forcing: Idealized Slab-Ocean Experiments with a GCM, J. Clim., 21, 3521-3532, doi:10.1175/2007JCLI2146.1, 2008.

\section{CPD}

doi:10.5194/cp-2015-156

\section{Interhemispheric bias in earth's climate response}

R. Roychowdhury and R. M. DeConto

\section{Title Page}

Abstract Introduction

Conclusions References

Tables

Figures

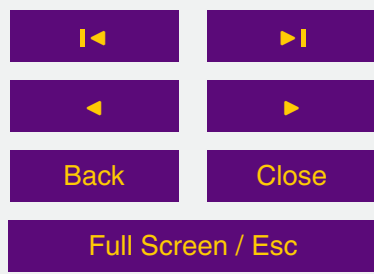

Printer-friendly Version

Interactive Discussion 
Kang, S. M., Seager, R., Frierson, D. M. W., and Liu, X.: Croll revisited: Why is the Northern Hemisphere warmer than the Southern Hemisphere?, Clim. Dyn., 1457-1472, doi:10.1007/s00382-014-2147-z, 2014.

Kiehl, J. T., Hack, J. J., Bonan, G. B., Boville, B. A., Williamson, D. L., and Rasch, P. J.: The National Center for Atmospheric Research Community Climate Model: CCM3*, J. Clim., 11, 1131-1149, doi:10.1175/1520-0442(1998)011<1131:TNCFAR>2.0.CO;2, 1998.

Koenig, S. J., DeConto, R. M., and Pollard, D.: Pliocene Model Intercomparison Project Experiment 1: implementation strategy and mid-Pliocene global climatology using GENESIS v3.0 GCM, Geosci. Model Dev., 5, 73-85, doi:10.5194/gmd-5-73-2012, 2012.

10 Lee, S.-Y. and Poulsen, C. J.: Amplification of obliquity forcing through mean annual and seasonal atmospheric feedbacks, Clim. Past, 4, 205-213, doi:10.5194/cp-4-205-2008, 2008.

Lisiecki, L. E. and Raymo, M. E.: A Pliocene-Pleistocene stack of 57 globally distributed benthic $\delta^{18}$ O records, Paleoceanography, 20, PA1003, doi:10.1029/2004PA001071, 2005.

Loutre, M.-F., Paillard, D., Vimeux, F., and Cortijo, E.: Does mean annual insolation have the potential to change the climate?, Earth Planet. Sci. Lett., 221, 1-14, doi:10.1016/S0012821X(04)00108-6, 2004.

Milankovitch, M.: Canon of Insolation and the Ice Age Problem, Zavod za Udz?benike i Nastavna Sredstva, Belgrade, 1941.

Philander, S. G. H., Gu, D., Lambert, G., Li, T., Halpern, D., Lau, N.-C., and Pacanowski, R. 20 C.: Why the ITCZ Is Mostly North of the Equator, J. Clim., 9, 2958-2972, doi:10.1175/15200442(1996)009<2958:WTIIMN>2.0.CO;2, 1996.

Raymo, M. E. and Huybers, P.: Unlocking the mysteries of the ice ages, Nature, 451, 284-285, doi:10.1038/nature06589, 2008.

Raymo, M. E. and Nisancioglu, K.: The $41 \mathrm{kyr}$ world: Milankovitch's other unsolved mystery, Paleoceanography, 18, 1011, doi:10.1029/2002PA000791, 2003.

Stone, P. H.: Constraints on dynamical transports of energy on a spherical planet, Dyn. Atmos. Ocean., 2, 123-139, doi:10.1016/0377-0265(78)90006-4, 1978.

Stouffer, R. J., Manabe, S., and Bryan, K.: Interhemispheric asymmetry in climate response to a gradual increase of atmospheric $\mathrm{CO}_{2}$, Nature, 342, 660-662, doi:10.1038/342660a0, 30 1989.

Thompson, S. L. and Pollard, D.: Greenland and Antarctic Mass Balances for Present and Doubled Atmospheric $\mathrm{CO}_{2}$ from the GENESIS Version-2 Global Climate Model, J. Clim., 10, 871-900, doi:10.1175/1520-0442(1997)010<0871:GAAMBF>2.0.CO;2, 1997.

\section{CPD}

doi:10.5194/cp-2015-156

\section{Interhemispheric bias in earth's climate response}

R. Roychowdhury and R. M. DeConto

\section{Title Page}

Abstract Introduction

Conclusions References

Tables Figures

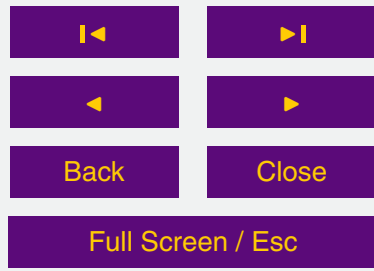

Printer-friendly Version

Interactive Discussion 
Trenberth, K. E., Fasullo, J. T., and Kiehl, J.: Earth's Global Energy Budget, B. Am. Meteorol. Soc., 90, 311-323, doi:10.1175/2008BAMS2634.1, 2009.

Wunsch, C.: The Total Meridional Heat Flux and Its Oceanic and Atmospheric Partition, J. Clim., 18, 4374-4380, doi:10.1175/JCLI3539.1, 2005.

\section{CPD}

doi:10.5194/cp-2015-156

Interhemispheric bias in earth's climate response

R. Roychowdhury and R. M. DeConto

\section{Title Page}

Abstract

Introduction

Conclusions

References

Tables

Figures

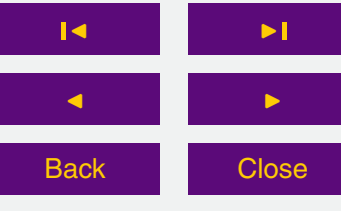

Full Screen / Esc

Printer-friendly Version

Interactive Discussion 


\section{CPD}

doi:10.5194/cp-2015-156

\section{Interhemispheric bias in earth's climate response}

Table 1. Experimental Setup of Model Boundary Conditions and Forcings.

\begin{tabular}{llrrll}
\hline Run ID & LSX Configuration & Eccentricity & Obliquity & Precession $^{\mathrm{a}}$ & GHGs \\
\hline CONTROL $_{\text {NHSP }}$ & Modern & 0.034 & 23.2735 & $270^{\circ}(\mathrm{NHSP})$ & Preindustrial \\
CONTROL $_{\text {SHSP }}$ & Modern & 0.034 & 23.2735 & $90^{\circ}(\mathrm{SHSP})$ & Preindustrial \\
CONTROL $_{\text {HIGH }}$ & Modern & 0.034 & 24.5044 & $180^{\circ}$ & Preindustrial \\
CONTROL $_{\text {LOW }}$ & Modern & 0.034 & 22.0425 & $180^{\circ}$ & Preindustrial \\
NORTH-SYMM $_{\text {NHSP }}$ & North-symmetric & 0.034 & 23.2735 & $270^{\circ}(\mathrm{NHSP})$ & Preindustrial \\
NORTH-SYMM $_{\text {SHSP }}$ & North-symmetric & 0.034 & 23.2735 & $90^{\circ}(\mathrm{SHSP})$ & Preindustrial \\
NORTH-SYMM $_{\text {HIGH }}$ & North-symmetric & 0.034 & 24.5044 & $180^{\circ}$ & Preindustrial \\
NORTH-SYMM $_{\text {LOW }}$ & North-symmetric & 0.034 & 22.0425 & $180^{\circ}$ & Preindustrial \\
SOUTH-SYMM $_{\text {NHSP }}$ & South-symmetric & 0.034 & 23.2735 & $270^{\circ}(\mathrm{NHSP})$ & Preindustrial \\
SOUTH-SYMM $_{\text {SHSP }}$ & South-symmetric & 0.034 & 23.2735 & $90^{\circ}(\mathrm{SHSP})$ & Preindustrial \\
SOUTH-SYMM $_{\text {HIGH }}$ & South-symmetric & 0.034 & 24.5044 & $180^{\circ}$ & Preindustrial \\
SOUTH-SYMM $_{\text {LOW }}$ & South-symmetric & 0.034 & 22.0425 & $180^{\circ}$ & Preindustrial \\
\hline
\end{tabular}

${ }^{a}$ Orbital precession in the GCM is defined here as the prograde angle from perihelion to the Northern Hemispheric vernal equinox. References
R. Roychowdhury and R. M. DeConto

\section{Title Page}

Abstract Introduction

Conclusions

Tables

Figures

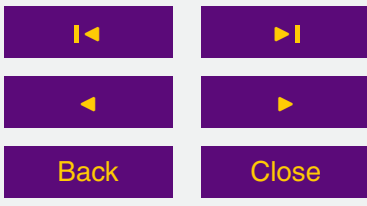

Full Screen / Esc

Printer-friendly Version

Interactive Discussion 
(a)

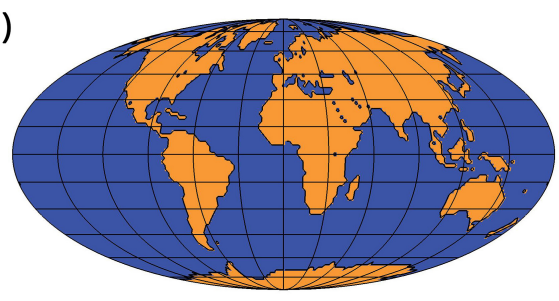

(b)

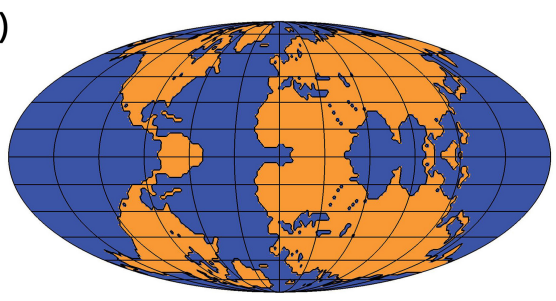

(c)

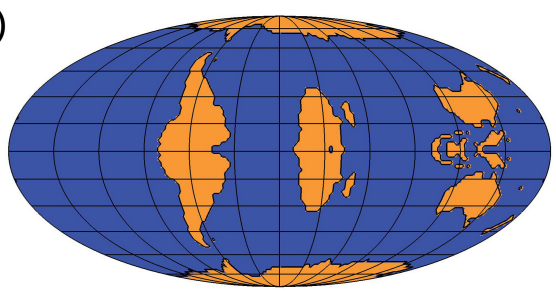

Figure 1. (a) Modern continental geography (b) NORTH-SYMM geography and (c) SOUTHSYMM geography.

\section{CPD}

doi:10.5194/cp-2015-156

Interhemispheric bias in earth's climate response

R. Roychowdhury and R. M. DeConto

\section{Title Page}

Abstract

Introduction

Conclusions

References

Tables

Figures

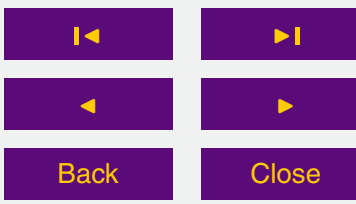

Full Screen / Esc

Printer-friendly Version

Interactive Discussion 
(a)

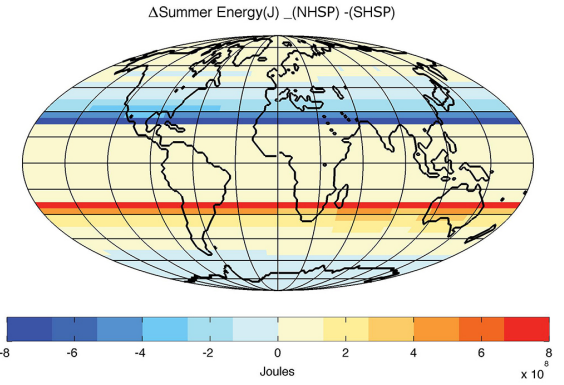

(c)

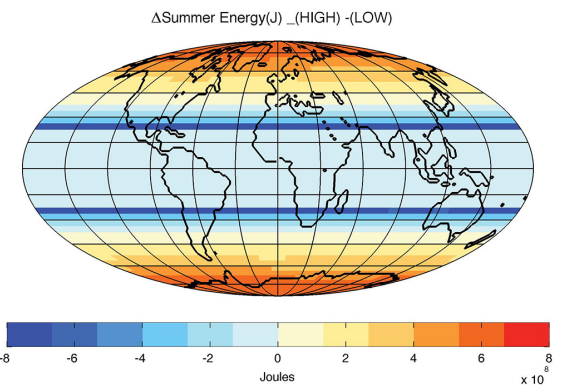

(b)

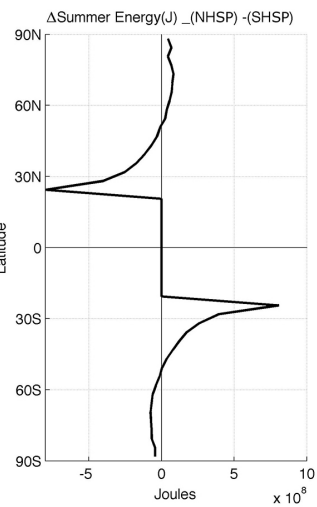

(d)

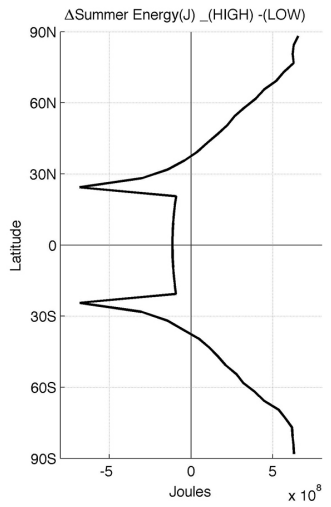

Figure 2. Changes in Summer Energy ( $J$, calculated at the top of the atmosphere) are symmetrical across the equator for any changes in orbital forcing. (a) Changes in $J$ corresponding to a change in the earth's orbit from NHSP (Northern Hemisphere Summer at Perihelion) to SHSP (Southern Hemisphere Summer at Perihelion), (b) latitudinal averages of the same, (c) changes in $J$ corresponding to a change in the earth's orbit from HIGH obliquity to LOW obliquity, and (d) latitudinal average of the same.

\section{CPD}

doi:10.5194/cp-2015-156

\section{Interhemispheric bias in earth's climate response}

R. Roychowdhury and R. M. DeConto

\section{Title Page}

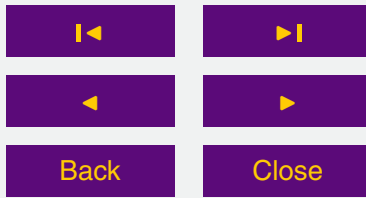

Full Screen / Esc

Printer-friendly Version

Interactive Discussion 
(a)

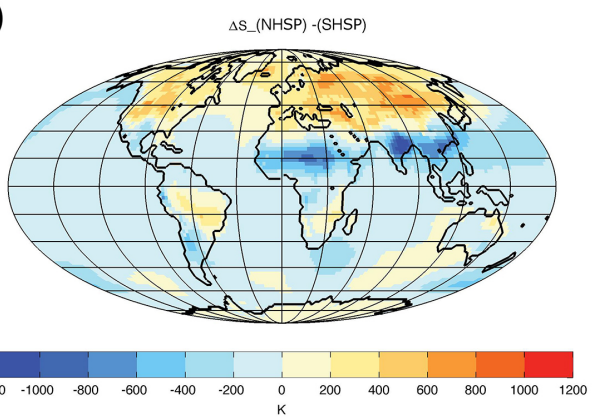

(c)

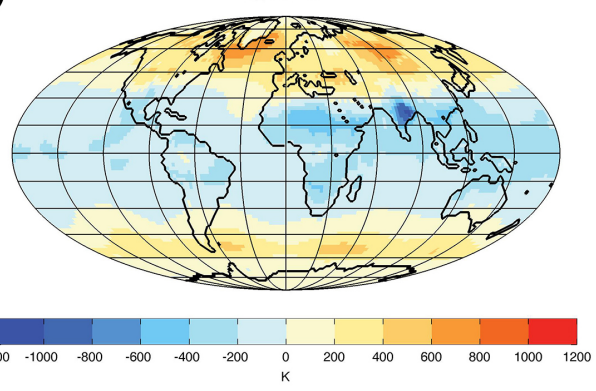

(b)

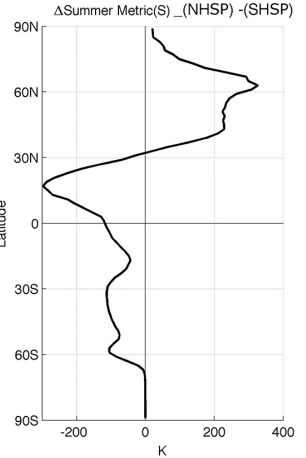

(d)

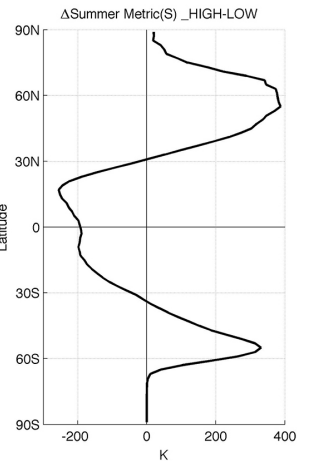

Figure 3. Changes in Summer Metric ( $S$, calculated as described by Huybers, 2006) show the asymmetric climate response of the earth to orbital forcing. (a) Changes in $S$ corresponding to a change in the earth's orbit from NHSP (Northern Hemisphere Summer at Perihelion) to SHSP (Southern Hemisphere Summer at Perihelion), (b) latitudinal averages of the same, (c) changes in the $S$ corresponding to a change in the earth's orbit from HIGH obliquity to LOW obliquity, and (d) latitudinal average of the same.

\section{CPD}

doi:10.5194/cp-2015-156

\section{Interhemispheric bias in earth's climate response}

R. Roychowdhury and R. M. DeConto

\section{Title Page}

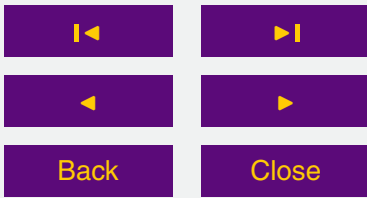

Full Screen / Esc

Printer-friendly Version

Interactive Discussion 
(a)

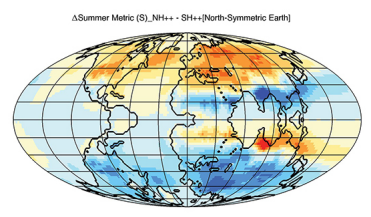

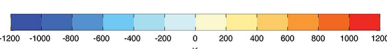

(c)

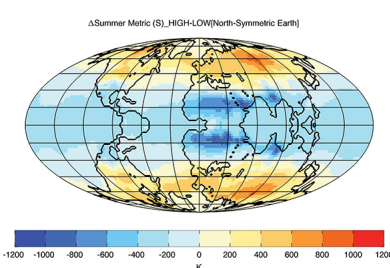

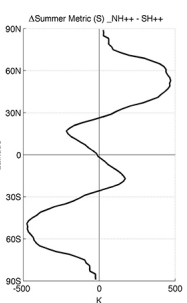

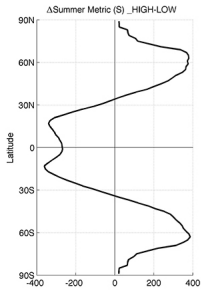

(b)

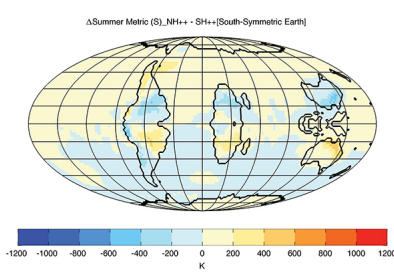

(d)

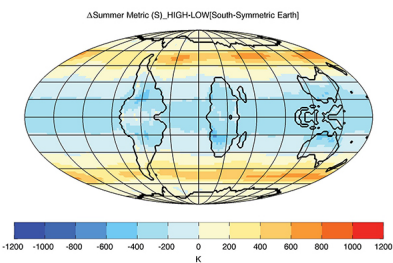

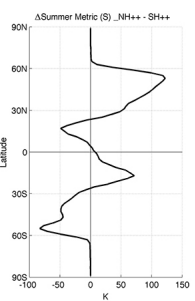

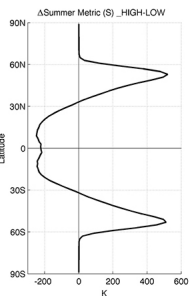

Figure 4. Changes in Summer Metric ( $S$, calculated as described by Huybers, 2006) show the symmetric climate response of the earth to orbital forcing in a meriodionally symmetric earth. (a-b) Changes in S corresponding to a change in the earth's orbit from NHSP (Northern Hemisphere Summer at Perihelion) to SHSP (Southern Hemisphere Summer at Perihelion) for (a) NORTH-SYMM geography and (b) SOUTH-SYMM geography; (c-d) changes in $S$ corresponding to a change in the earth's orbit from HIGH obliquity to LOW obliquity for (c) NORTHSYMM geography and (d) SOUTH-SYMM geography.

CPD

doi:10.5194/cp-2015-156

Interhemispheric bias in earth's climate response

R. Roychowdhury and R. M. DeConto

\section{Title Page}

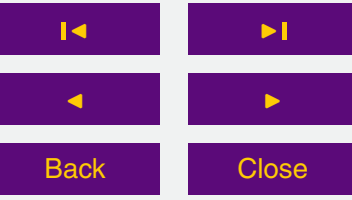

Full Screen / Esc

Printer-friendly Version

Interactive Discussion 


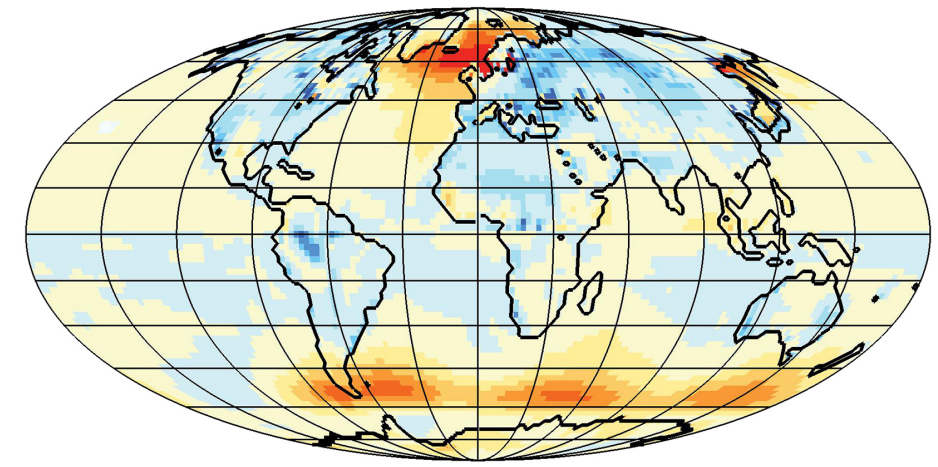

\section{CPD}

doi:10.5194/cp-2015-156

Interhemispheric bias in earth's climate response

R. Roychowdhury and R. M. DeConto

\section{Title Page}

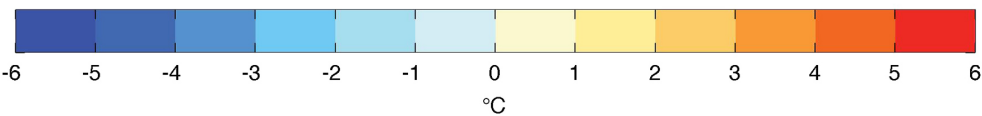

Figure 5. Estimated Land Hemispheric Bias (LHB) in surface $(2 \mathrm{~m})$ air temperatures for present day continental geography and orbit.

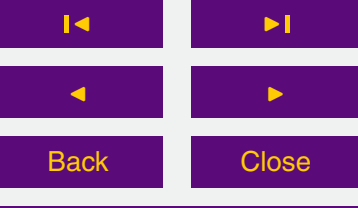

Full Screen / Esc

Printer-friendly Version

Interactive Discussion 
(a)

Bias Map corresponding to NHSP
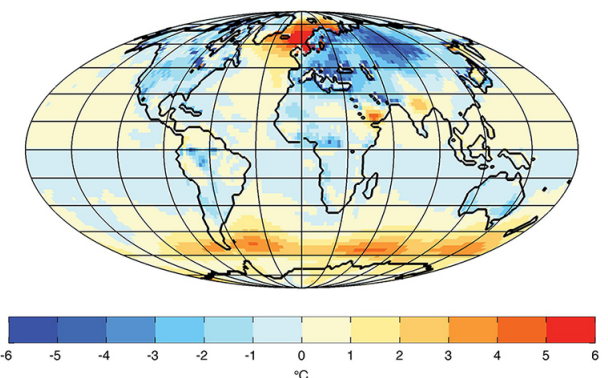

(c)

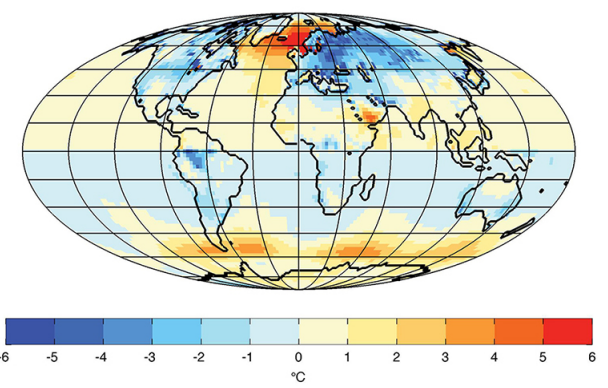

(b)
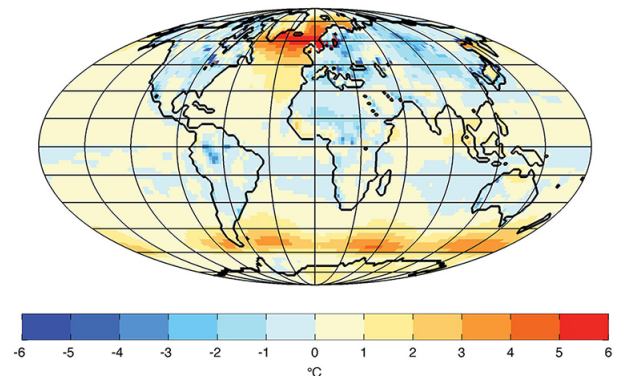

(d)

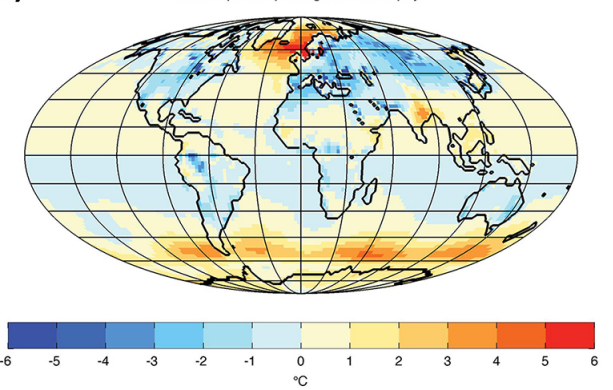

Figure 6. Estimated LHB in surface $(2 \mathrm{~m})$ air temperatures for present day continental geography and extreme orbits: (a) Northern Hemisphere Summer at Perihelion (b) Southern Hemisphere Summer at Perihelion; (c) high obliquity and (d) low obliquity.

\section{CPD}

doi:10.5194/cp-2015-156

\section{Interhemispheric bias in earth's climate response}

R. Roychowdhury and R. M. DeConto

\section{Title Page}

Full Screen / Esc

Printer-friendly Version

Interactive Discussion

(c) (1) 